The Geneva Papers on Risk and Insurance, 21 (No. 79, April 1996), 170-181

\title{
Extended Producer Responsibility Recycling, Liability, and Guarantee Funds*
}

\author{
by Karl Lidgren** and Göran Skogh*** \\ with a comment by Walter Stahel
}

\section{Introduction}

An important extension of the environmental policy in many countries is the introduction of "extended producer responsibility". The "extended responsibility" is related to the retaking and recycling of used goods. The term "producer" is usually widely interpreted and may include anyone in the chain of suppliers, manufacturers, dealers, and importers. The general idea is that if a profit-maximising firm connected to the early stages of the production process is made liable, it will have an incentive to minimise recycling costs. ${ }^{1}$ The costs may be reduced by the choice of raw materials, design, processing, or composition of the goods. Dangerous metals and plastics may be substituted, welded parts may be applied in such a way to make dismantling easy, etc. Another means of reducing recycling costs is to prolong the life of the goods through better quality and service. A long-term expectation is that exchanged raw materials, reorganised production, new systems of returns and dismantling, etc., will make the recycling privately profitable. ${ }^{2}$

* This article is a revised version of a report to the Swedish Official Investigation «Avfallsfri Framtid»(A Waste-free Future) SOU 1994:114, see SKOGH [1994].

** Professor, Director of the International Institute of Industrial Environmental Economics at Lund University.

*** Associate Professor at the International Institute of Industrial Environmental Economics and the Department of Economics, Lund University.

${ }_{1}^{1}$ The general philosophy behind the movement toward extended producer responsibility recognizes the need of a sustainable development and a "circular view" in economics, see STAHEL [1994].

${ }^{2}$ Profitable recycling takes place already today. For instance, spare parts are taken from used cars, and the metal in the body and engine is re-used. The social problem concerns limited returns and the possiblity of dangerous substances polluting the environment. Deposit systems are used in some countries to make return profitable for batteries, tyres, and cars. 
There are several basic matters regarding extended producer responsibility that need to be clarified. A first question is: Which goods shall be included in the producer's responsibility - shall used cars, as well as household garbage, be included? In the end, it is consumers who pollute by littering and by throwing away TV sets, furniture, and other worn-out goods. Homeowners are usually responsible for household garbage, so why should they not also be responsible for manufactured durable goods? A second question is: How far-reaching shall the recycling be? Which percentage of returns is acceptable, which substances and components shall be separated, and which shall be re-used? ${ }^{3}$ A third question is related to the fact that usually not just one producer is involved. Who should be liable when several suppliers, producers, and distributers are involved? A fourth question is related to enforcement of the producer's responsibility. Fraudulent behaviour may be serious. The liable producer may also become insolvent. The insolvency problem is especially obvious for durables with a life span of many years - the accumulated economic liability of sold (but not yet recycled) goods will add to the bankruptcy risk.

In this article, we study the recycling responsibility for durable goods sold in large numbers to consumers or firms. We address two of the basic questions above: (i) Which party in the production and recycling process should be responsible for all, or part, of the recycling? In "recycling responsibility" we include responsibility for the return, collection, storage, and re-use of worn-out goods. The responsible party is supposed to be legally liable when not fulfilling its duty. (ii) How should recycling be guaranteed? We limit the study to durable goods with an expected life span of 5-20 years. When the goods are worn out, the initial producer may have disappeared; and if the liable party exists, it may be unable to cover the recycling costs. Moreover, new information on dangerous waste will have become available at the end of the life cycle of the goods. Some measures are, therefore, needed to ensure the recycling.

The outline is as follows: first, we present a case in which liability for recycling is placed on a fully integrated firm. The firm both produces the durable and recycles it. This extreme case is, then, compared to a firm that contracts with other firms, both for production and for recycling. It is shown that the efficiency of recycling liability depends on transaction costs, and on the ability of public authorities to enforce the law by supervising suppliers, producers, dealers, and consumers. ${ }^{4}$ Thereafter, we examine how recycling may be ensured 10-20 years after the goods have been sold. Because recycling (a proper ending of a good's life) requires huge funds, it may be necessary to employ reserves of the same type as funeral, pension, or life insurance funds. Indeed, in the future we expect a new financial recycling industry to develop. The study so far concerns goods not yet sold. A remaining problem treated at the end of the article is how the recycling of goods already in use may be ensured. A summary with some concluding remarks ends the article.

\section{The integrated firm}

We start by studying recycling liability involving one producer who is also liable for the recycling. Production is integrated in the sense that the entire process of production

\footnotetext{
${ }^{3}$ Recycling must be mandatory because of the social goal to re-use more than what is privately profitable.

${ }^{4}$ This is an application of the Coase Theorem, see Ronald COASE [1960].
} 
and distribution, as well as recycling, is controlled within the firm. Hence, the producer retakes, dismantles, and re-uses the worn out good. The profit-maximising firm has an incentive to minimise the costs of recycling, given the standards set by the authorities.

The firm's economic liability caused by sold, but not yet recycled, goods may be large. Therefore, a first requirement of the owners of the firm, the creditors, and the environmental authorities is that this debt be accounted for in the books. This accounting requires calculations that may be complicated because of the length of time between sales and recycling. Over time, recycling may become either more expensive or cheaper. ${ }^{5}$

There are many reasons why a firm may go bankrupt, which would then jeopardise recycling of its goods. Therefore, a separation of recycling liability from other liabilities of the firm may be necessary to insure the recycling. Such a recycling reserve would have much in common with a funeral, life, or pension fund. These funds are often held as separate legal entities to guarantee liability at insolvency of the firm. The main difference is that a pension fund covers costs after an active life, while a recycling fund covers costs of handling worn-out goods. The financial problems are similar, however, in spite of the differences between goods and human individuals.

Note that with the establishment of a separate fund the firm is no longer fully integrated. Indeed, it is not only the insolvency risk that motivates transactions with other independent organisations. It is usually profitable to purchase intermediary goods and services. It may also be profitable to pay for the return, storage, and dismantling of worn-out goods. Should such trade of recycling be permitted? Would that not miss the idea of the producer's recycling liability?

\section{Negotiations without transaction costs}

Before answering the above questions, we describe briefly a hypothetical situation where the party responsible for recycling can negotiate and contract without transaction costs, such as search, negotiation, contracting, and enforcement of a contract. We assume that the involved firms maximise profits, there is no insolvency problem, and the authorities' control of recycling is cost-free. Moreover, there are no restrictions in the freedom to contract. The party liable for the recycling costs is, thus, free to contract both work and liability to others. Given these assumptions, the Coase Theorem (1960) stipulates that recycling will be done in a cost-efficient way, regardless of who is initially legally liable for the recycling.

To illustrate, assume that there is one supplier of raw materials, one producer, one dealer, one buyer, and one recycling firm. The producer is legally liable for the recycling. Due to the free transfer of rights and duties, the producer will contract with the supplier on materials that simplify the recycling process. The producer may also contract with the dealer on the collection and return of used goods. Thereafter, the dealer may contract with the buyer to return the goods (perhaps through the use of a deposit). The producer may also contract with the recycling firm for dismantling and the sale of regained materials. here.

${ }^{5}$ The accounting of recycling liability also has consequences for taxation, but that is not treated 
Now, assume instead that the legislator has made the final consumer/owner liable for recycling. Because of costless and free transactions, the owner may contract with the involved parties in a way that minimises the costs of recycling. The dealer may, thus, accept the used goods in return. Next, the dealer contracts with the recycling firm. The recycling firm may contract with the producer in order to reduce the recycling costs, and the producer may contract with the supplier of materials. Another possibility is that the producer accepts the recycling liability. A producer with a comparative advantage in assuning the responsibility will have an incentive to do so. Then, the producer may contract with the supplier and the others involved, as outlined above.

Similarly, if the dealer is legally liable, she may contract with the consumers to return the goods, the producer to change the design, the recycling firm to handle the recycling responsibility, etc. Independent of the initial legal responsibilities, it is in the common interest of the involved parties to redistribute the tasks and liabilities according to comparative advantages.

Which party in this chain will finally carry the recycling costs? It depends on the ability to transfer costs via the pricing of the separate services and the durable good. Hence, there is no simple answer. However, the simplistic view that the producer carries the recycling cost of the producer's recycling liability, and that the consumer carries the cost of the consumer's liability is not well-founded. The outcome depends on market conditions. With perfect competition, i.e. with no excess profits in the industry, the consumer will have to pay for the recycling, independent of the initial legal recycling liability. It, thus, seems a reasonable first assumption that consumers will end up paying for recycling, regardless of the initial legal liability.

\section{Transaction costs}

Above, we assumed zero transaction costs, which seems to be fairly realistic in an industry producing and recycling durables. Transaction costs are relatively low when a limited number of firms are involved in repeated dealings. The producers, suppliers, and dealers know each other relatively well, and their respective performances are controlled by the value of a good reputation. The legislator may, therefore, place the recycling liability on any of the parties involved in the production and recycling processes without loss of efficiency.

If, on the other hand, the recycling liability is placed on the final consumer, the outcome may cause inefficiency. The individual consumer has no comparative advantage in the recycling of durables, except for the returning. He must, therefore, transact most of the recycling to other links in the chain. These transactions are not without costs because of the large number of consumers, their lack of experience, and the user's limited ability to control the quality of the recycling. For example, assume that the owner of a TV set is liable for the recycling of that item. It is complicated, if not impossible, for the single owner to recycle a TV. Profit-seeking dealers and/or producers of TV sets may, therefore, offer recycling at a price. In the end, recycling may be standardised and included in the price of a TV set when it is new; however, that development will take time. Furthermore, it may be difficult to enforce consumer liability. TV sets may be left in the woods or stored in attics without recycling. In such cases, excessive fining may not be a sufficient measure to deter a considerable portion of the TV owners. 
Obviously, it is a detour to make consumers legally liable for recycling. A way of reducing the transaction costs, and, thus, increasing the efficiency of recycling, is to place the legal liability directly on the party that has the comparative advantage in the recycling process. By simulating free contracting under the assumption of no transaction costs, as we did above, the legislator may identify cost-efficient recycling liability. An efficient law would make that party liable that accepts the liability freely in a world without transaction costs. Hence, an efficient law makes no further transactions necessary. The perfect law is not possible in practice, but by making the producer liable for the dismantling and re-use of materials, the dealers responsible for collection, and the consuniers for returning the goods, further transactions are limited to low-cost dealings among the traders in the industry.

The principle encompassing comparative advantage and transaction costs explains why, for instance, households are liable for garbage from the kitchen. There are no apparent comparative advantages in making farmers liable for the waste; and there are no direct and simple negotiations and contracts between farmers and consumers such that the liability can be transacted to the consumers.

\section{The right to transact liability by contract}

So far, we have assumed that the public authorities can enforce recycling liability without difficulty. In reality, however, the cost and possibility of controlling the parties varies. The control of thousands of consumers could be costly, it might also be complicated to control a large number of dealers, and foreign producers might well be impossible to control. Therefore, the question of who is liable is of importance, and the right to transfer liability by contract must be limited. For example, a legally liable producer contracts with other firms for the dismantling and storage of waste. Later, it is shown that the recycling has not been completed because of incompetence, fraud, or insolvency. If it has been legally acceptable for the parties to transact the liability, then recycling cannot be enforced. Therefore, the extent to which the legislator may be motivated to limit the freedom of contract is an important issue.

The question of vicarious liability has been addressed in the literature. A general rule is that, if a party is solvent and able to control the others involved at low cost, it is efficient to make this "principal" vicariously liable. Hence, this liability should not be allowed to be tranfered by contract to an insolvent, incompetent, or fraudulent party. The principal may, of course, contract on various goods and services, but at the principal's own risk. In other words, if the parties involved in the recycling do not fulfil their duties, the principal remains liable. The principal must, thus, control the others, which may be done at low costs (relative to public supervision and control) due to repeated exchange among the parties. The legislator can, therefore, without loss of efficiency, make the principal liable for the failures of others. Thus, public enforcement is simplified - supervision is concentrated on a solvent party, which in turn is able to control its contractors. Similar vicarious liability is frequently applied in bank guarantees and in employer's liability at the workplace. ${ }^{6}$

${ }^{6}$ See SHAVELL[1987], SYKES [1984], and SKOGH [1991]. 
A common problem arises with imports in that the producers cannot be controlled by the public authorities, thus providing a reason for making an extra link in the chain of involved parties liable -.- the importer. However, importers are usually small firms that may leave the market or become insolvent, which brings us to the question of how recycling can be guaranteed in cases where the principal goes bankrupt or disappears for other reasons.

\section{Recycling funds}

As noted above, one way to guarantee recycling is to build up recycling reserves. For instance, the liable party (producer or importer) may pay an amount to a separate and independent fund for each sale of the durable. The liability is, thereby, transferred to a fund, which becomes the principal. Let us assume that the fund is profit-maximising. It will have an incentive to minimise recycling costs within the constraints set by the authorities and will, as would any other principal, contract on services with consumers and firms, including the initially liable producer or importer.

Mandatory recycling must be supervised. This is also true for separate recycling funds. The control problem appears smaller, however, in the situation where a producer or importer is liable and keeps the reserves fund within the firm. If payments to the fund for recycling are based on the sales of the goods, the fund and the authorities will have a common interest in the registration of all sales. This may simplify the accounting of recycling liability. A way of ensuring that most used goods are returned is to offer a deposit large enough to motivate the consumers to return the goods. The amount of the deposit may be set by the authorities.

One obstacle may be that the fund has an interest in cheap (low quality) recycling. On the other hand, an advantage to a separate financial firm as principal is that it is the organ that purchases recycling services. Such services can be inspected by the authorities before they are paid - and in the case of unacceptable recycling practices, payment can be withheld.

Above, we pointed out the similarities between a recycling guarantee fund and a pension plan. There are differences, however. The yearly pension paid at retirement is usually fixed in advance, while the costs of recycling depend on collection, dismantling, and storage costs in a future system, as well as on the value of regained materials. Thus, the recycling guarantee is a riskier business, and in this respect resembles health insurance, which covers treatment without limitation. A problem with health insurance is that the availablity of insurance coverage tends to generate an increased demand for treatment. Unlimited insurance coverage may also reduce the efficiency of the treatment. One way for the insurer to control costs is to contract with certain hospitals or clinics for treatment. A similar situation prevails in a recycling fund system. The fund has an incentive to contract with suppliers, producers, distributors, and consumers in order to keep down costs.

Cost-efficient recycling requires that the fund be fully liable. If the fund receives extra contributions or subsidises losses, or if part of the profit is confiscated, the incentive to reduce costs will diminish. Implementation of recycling liability (including the size of consumer deposits) is of vital importance for the profitability of the fund. It is, therefore, important that recycling requirements are clearly specified. For instance, if the fund makes 
large profits, it may be tempting to increase the required recycling. Similarly, with a loss there may be a pressure in favour of decreased recycling. ${ }^{7}$ Hence, the fund may have some difficulities in protecting its interests. It should be noted, however, that these difficulties would be larger in a system where single producers are responsible, the reason being that a relatively large fund can negotiate with the authorities on more equal terms. It may also be in the interest of the authorities to have a limited number of counter-parties that are fairly strong and specialised in the recycling business.

\section{Who should own the fund?}

So far, we have assumed that the fund is profit-maximising, and that the recycling premiums paid in advance are fixed, together with the required recycling standard. This results in a considerable business risk. After 10 to 15 years the recycling cost may have changed considerably. In a successful scenario, recycling has become profitable without coverage by the reserves. On the other hand, the cost of recycling may increase and the value of the reserves may be watered down by inflation. The assets of the fund may also increase (decrease) in value due to a high (low) return. To reduce the risk of bankruptcy (which may in practice force the authorities to reduce the recycling standard), the premiums may be set with a margin. If so, the fund can expect to make a profit.

This riskiness provides a reason for organising the recycling reserves as a mutual fund. Long-term life insurance and pension funds also have an uncertain outcome, especially due to variations in the return on assets. That may explain why such insurances are normally organised as mutuals, with the policyholders as owners. If there is a profit, it will be distributed among the policyholders, and with a loss additional contributions will be required.

A shortcoming with mutual funds is that the ownership is spread, which reduces the incentive for profit-maximising behaviour. This problem diminishes in importance, however, as long as the number of owners is small. Mutuals with thousands of policyholders/owners may be "without ownership" and, thus, without efficient internal control. For a mutual recycling fund, with a small number of producers/importers of durables as owners, the problem is much smaller. Indeed, in a small group owners have an incentive to control each other.

Another problem related to mutual ownership is that the firm does not have the same access to capital as does a widely held stock company. However, since the purpose of the fund is to administer a given amount and guarantee recycling, there is no apparent need for large investments and, hence, no need for external capital.

A similar ownership structure is one in which some producers/importers, together with recycling firms and dealers, own the equity of the fund. The parties involved in the recycling have a common interest in minimising recycling costs, which simplifies the contracting and the control among the parties. Note that we are back to integrated recy-

${ }^{7}$ The fund system discussed here concerns future products. It may be tempting for politicians and authorities to use the funds also for recycling of goods that are not financed, but that would water down the reserves and the incentive to recycle efficiently. 
cling liability, although not in one firm but in many integrated by mutual or stock ownership (cf. section 2).

\section{Competition among funds}

Given a recycling law and a recycling standard specified in general terms, combined with secured or guaranteed recycling as a requirement for the right to produce (or import) durables, we can expect the establishment of reserves and funds of various size and structure. Large firms and industry groups may establish their own funds. Branch associations may organise the funding for some durables. Already established insurance companies may also go into the business. Importers of office equipment such as telephones, faxes, and computers may start their own funds, while domestic producers may choose their fund. A fund may, of course, guarantee several durables. The funds will develop skills in administration, in the writing of collection and dismantling contracts, and in the control of recycling. Since different durables require different recycling procedures, and thus special knowledge, we expect that the funds will specialise in different durables.

Huge assets may be concentrated in the funds. For example, assume that the premium for the transaction of recycling liability to the fund is 10 percent of the total sales of the durable. The premium is expected to cover all future recycling costs. We assume that the life span of the good is 10 years, the interest rate is 5 percent, and there is no inflation. After ten years when the fund is to be used and the growth of the reserve has ended, the fund will have reached 1.26 of the yearly sales of the durable. Hence, if most durables are covered by this type of system, the funds will be very large. If there are few funds, they may obtain market power as a consequence. However, it is only within a national perspective that these funds may become large. In the global financial market the funds will remain small. A national problem may be that a fund with large resources might also control the pricing of domestic durables. A related problem concerns the entry fees for entering a fund and the compensation at exit. A large entry fee and a small exit compensation may be used to reduce competition. For these reasons, anti-trust laws may have to be applied.

\section{Durables already in use}

The system outlined above is designed for durables not yet in use. The establishment of a fund system will take time, and the resulting recycling practices will first start some years after the system is introduced. Therefore, a problem remaining is how to handle the recycling of durables already in use.

One purpose of recycling liability is to encourage the producer to design products, return systems, and dismantling procedures in a cost-minimising way. For durables already in use, the product design is given and cannot be improved; yet recycling liability may be used for the collection, dismantling, and re-use of materials. As noted above, the consumer/owner presumably has a comparative advantage in the return of the goods. It is, thus, necessary to motivate the consumers to undertake the returns. One way is to pay consumers a sum large enough to motivate them. However, the financing of such a plan may create problems. If the dealers or producers are liable for the returns, it is they who need to pay the consumers. Since the goods have already been sold and returns not calculated in 
the prices, this would result in windfall losses for the dealers/producers. Payment by public means is possible, of course, but presumably not politically attractive.

An alternative is to make the consumer (the owner) liable for the return. ${ }^{8}$ Consumer liability for returns requires that sanctions like damages or fines be used if the obligation is not fulfilled. Accountability is not easily put into practice, even though thrown away durables may have some form of inscription, or other markings, which make it possible to identify and fine the owner. Penal sanctions require that offenders be detected without excessive policing costs; however, all littering will not be detectable. Heavy fining and extensive policing efforts may, therefore, be necessary. In addition, penal sanctions require that the idea of consumer responsibility become generally accepted, which would seem to be only a minor problem. The understanding that recycling is important and that consumers have a moral responsibility appears to be widely spread.

A financial advantage to consumer return liability is that the costs of returns are carried by the consumers/owners. Thus, it may be politically attractive to allocate the return duty to the consumers. However, the policing and littering costs must also be taken into consideration. The remaining costs for recycling need to be covered by taxes if windfall losses are to be avoided in the business.

Finally, it should be noted that a general obligation to return used durables would result in a large amount of collected waste. The recycling standard needs to be settled upon, and the dismantling financed for a large number of goods. It seems reasonable, therefore, to concentrate on certain goods, primarily on those of large volume, which require considerable space at dumping sites, and on those with dangerous substances.

\section{Summary and concluding remarks.}

A recycling law is needed to insure the recycling of durables that are not privately profitable to recycle. Moreover, the authorities who implement the recycling law need to specify the recycling standard, for instance, in terms of what percentage of the used good is to be recycled.

Once this is done, the authorities need to decide which party shall be liable for recycling. When the producers, suppliers, dealers, and final users can easily transfer services by contract, liability can be placed efficiently on any of those involved, regardless of who is liable, because the participants have a common interest in distributing tasks relative to their comparative advantages.

This conclusion rests on the assumption that the authorities have no problem in controlling the different parties. It may, however, be difficult to control a large number of consumers or suppliers. It is simpler to control few producers, which provides a rationale for producer recycling liability. For imported goods, the liability may be placed on the importer.

${ }^{8}$ Owner's, instead of the consumer's, liability is a form of vicarious liability. The rationale for making the owner the principal is that the owner may control the return. Moreover, the owner is usually possible to be identified and therefore, to be made accountable to pay damages or fines. 
Cost-efficient recycling requires that the liable party be free to contract services to suppliers, dealers, and consumers. However, in order to enforce liability, it may be efficient not to allow the liable producer/importer to transfer liability to other parties. Contracts on services with other parties would be at the "principal's" own risk if this does occur.

Thus far, conclusions rest on the assumption that the parties involved in the production, sales, and recycling of the goods can trade without serious transaction costs. If they cannot, it may be of public interest to place the liability directly on the party with comparative advantage in the recycling activity in question. Therefore, it may be reasonable to make the consumer liable for returns, the dealer liable for collection, and the main producer liable for dismantling.

To insure recycling in case of insolvency, a system of recycling funds is discussed. The suggested system includes a premium given $e x$ ante for the transfer of liability to the fund. The fund, thereby, assumes liability and will contract with dealers, consumers, producers, and suppliers for the recycling of the goods. Because it is complicated to foresee the costs of recycling, the premium will be arbitrary and the profits or losses may be large. Therefore, mutual or shared fund ownership, with producers and/or dealers as owners, may be preferred. One advantage with such funds is that recycling is guaranteed. Another is that it simplifies negotiations with the industry and the authorities' control of both accounting and performance.

Once there is a law calling for recycling liability, including a requirement for a reserve fund to insure the recycling, we may expect different funds and insurance plans to arise, depending on the industry and products involved. Just as the proper end of the life of durable goods will be similar to the end of human lives in the future, so will the recycling requirements engender solutions similar to health, life, and pension insurance. Accordingly, these recycling reserves will generate savings in the same way as life and pension reserves. A developed system of recycling funds will result in an important new financial industry that will contribute considerable capital to the financial markets.

\section{REFERENCES}

COASE, R. [1960] "The Problem of Social Costs," Journal of Law and Economics.

SHAVELL, S. [1987] An Econornic Analysis of Accident Law. Harvard University Press.

SKOGH, G. [1991] "Insurance and the Institutional Economics of Financial Intermediation," Geneva Papers of Risk and Insurance, No. 58.

SKOGH, G. [1994] "Förlängt producentansvar med kretsloppsgaranti. (Extended Producers Rersponsibility with a Recycling Guarantee)," In SOU 1994:114, pp. 335-352.

STAHEL, W. [1994] "Retake and Recycling," The Product-Life Institute, Memo.

SYKES, A. [1984] "The Economics of Vicarious Liability," Yale Law Journal, vol. 93, pp. 1231-1280. 